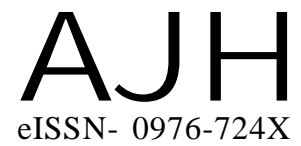

Received : 30.01.2017

Revised : 07.05.2017

Accepted : 21.05.2017
Members of the Research Forum

Associated Authors:

'Department of Applied Plant

Science (Horticulture), Babasaheb

Bhimrao Ambedkar University,

LUCKNOW (U.P.) INDIA
Author for correspondence : SUTANU MAJI

Department of Applied Plant Science (Horticulture), Babasaheb Bhimrao Ambedkar University, LUCKNOW (U.P.) INDIA

Email : majisutanu@gmail.com
THEASIAN JOURNALOF HORTICULTURE

Volume 12 Issue $1 \mid$ June, 2017 | 121-126

Visit us -www.researchjournal.co.in

DOI : 10.15740/HAS/TAJH/12.1/121-126

\section{Effect of plant bio-regulators on the growth, yield and physico- chemical characteristics of onion (Allium cepa L.)}

\section{SANJAY KUMAR ${ }^{1}$, SUTANU MAJI AND KAMAL RAM MEENA ${ }^{1}$}

ABSTRACT : This experiment was held to study about the efficacy of concentration of plant bio regulators on vegetative growth, yield and quality characters of onion cv. NHRDF-RED-2 under Lucknow subtropical condition having dry climate and high $\mathrm{pH}$ soil (8.2). The experiment comprised of 13 treatments [Control (water spray), GA @ 50,100 ppm, 150 ppm; NAA @ 50 ppm, 100 ppm, 150 ppm and combination of $\mathrm{GA}_{3}$ and NAA] laid out in the Randomized Block Design with three replications. The observations revealed that the application of $\mathrm{T}_{11}\left[\mathrm{GA}_{3} @\right.$ $100 \mathrm{ppm}+$ NAA @ $100 \mathrm{ppm}]$ was better for improvement of growth i.e. plant height $(76.50 \mathrm{~cm})$, number of leaves (8.27), length of leaves $(60.60)$ and basal diameter $(2.05 \mathrm{~cm})$ at $90 \mathrm{DAT}$. It also recorded the highest bulb yield $(60.34 \mathrm{t} / \mathrm{ha})$, fresh weight $(90.51 \mathrm{~g})$, dry weight $(10.89 \mathrm{~g})$, diameter (6.87 and $6.87 \mathrm{~cm}$ equatorial and polar, respectively) of onion bulb. Similarly, chemical properties like TSS $\left(12.03^{\circ} \mathrm{B}\right)$ and $\mathrm{pH}(6.99)$ was found better under treatment $\mathrm{T}_{11}\left(\mathrm{GA}_{3} @ 100 \mathrm{ppm}+\mathrm{NAA}\right.$ @ $100 \mathrm{ppm})$ followed by $\mathrm{T}_{9}\left(\mathrm{GA}_{3} @ 50 \mathrm{ppm}+\mathrm{NAA} @ 150 \mathrm{ppm}\right)$. Thus, the study suggested that combined application of bio regulators $\left(\mathrm{GA}_{3} @ 100 \mathrm{ppm}+\mathrm{NAA} @ 100 \mathrm{ppm}\right)$ may be followed to get better growth, yield and quality of onion cv. NHRDF-RED-2 under drier subtropical climate.

KEY WORDS : Bio-regulators, GA 3 , Growth, NAA, Onion, Quality, Yield

HOW TO CITE THIS ARTICLE : Kumar, Sanjay, Maji, Sutanu and Meena, Kamal Ram(2017). Effect of plant bio-regulators on the growth, yield and physico- chemical characteristics of onion (Allium cepa L.). Asian J. Hort., 12(1) : 121-126, DOI : 10.15740/HAS/TAJH/12.1/121-126. 